\title{
Diversity and distribution patterns of medium to large mammals in a silvicultural landscape in south-eastern Brazil
}

\author{
Bruna Manuele Campos, \\ Jacob Daniel Charters, \\ Luciano Martins Verdade
}

\begin{abstract}
Agricultural landscapes cover approximately 35\% of Brazil and are the second greatest threat to biodiversity worldwide. In Brazil, seven millions hectars of land is covered with Eucalyptus plantations, which is considered to have low conservation value. However, studies have shown that heterogeneous silvicultural landscapes, made up of Eucalyptus matrices and patches dedicated to conservation, are able to support a considerable diversity of wild mammals. This study aims to assess the diversity and distribution patterns of medium-tolarge-sized mammals in a silvicultural landscape in Angatuba, São Paulo, Brazil. Nineteen species were detected by camera traps within the study area. Diversity indices did not vary among habitat types (i.e., native vegetation, abandoned pasture and Eucalyptus plantations), suggesting that the species use the landscape as a whole. A relatively diverse range of predator species was found in the area, suggesting that future monitoring programs should focus on predator-prey relationships. A low diversity of frugivores was detected, indicating that management actions should be taken to facilitate their local recovery. Our results stress the fundamental importance of the conservation areas (Permanent Preservation Areas and Legal Reserve) in silvicultural landscapes, as these areas help maintain complexity of the landscape structure.
\end{abstract}

Keywords: Agroecosystem, Wildlife Management, Mammals, Eucalyptus, Camera-trapping

\begin{abstract}
Introduction
Approximately $35 \%$ of Brazil is covered by agricultural landscapes (World Bank 2018), in which vast areas of native vegetation have been cleared and cultivated with soybean, sugarcane, maize, exotic pasture (i.e., Brachiaria spp.) and Eucalyptus plantations (Sparovek et al. 2010). The exact date when Eucalyptus species were introduced to Brazil is unclear. However, around 1904, seedlings were brought from Australia to São Paulo, with the aim of producing wood for charcoal, and often replaced areas of pasture that were no longer viable for cattle grazing (Cianciulli 1954). The rapid growth rate of genetically modified Eucalyptus trees, primarily harvested to produce cellulose, paper and charcoal, along with the high commodity value, drove the rapid expansion of this industry throughout eastern Brazil, which now covers

around seven million hectares (IBGE 2015). Worldwide, land use change for agriculture is considered to be the second most significant threat to biodiversity (Maxwell et al. 2016), as it causes negative impacts on native ecosystems through habitat destruction and fragmentation, soil, air and water pollution, and facilitates the spread of exotic species (Foley et al. 2005). However, some characteristics of these landscapes appear to offer significant conservation value. Eucalyptus plantations present a strong temporal heterogeneity in biomass, as these plantations have a fast grow-cut-replant cycle, varying between zero and $300 \mathrm{~m}^{3} \mathrm{ha}^{-1}$ year ${ }^{-1}$ in biomass (Stape et al. 2004), affecting ecological processes and, ultimately, changing biodiversity patterns (Martin et al. 2012). Additionally, the environmental certification process (e.g., Forest Stewardship Council)
\end{abstract}

$\square$ University of São Paulo, CENA, Isotopic Ecology Laboratory, P.O. Box 96, Piracicaba, SP 13416-000 (Brazil)

@ Bruna Manuele Campos (brunamanuelecampos@gmail.com)

Received: Jan 04, 2018 - Accepted: Oct 16, 2018

Citation: Campos BM, Charters JD, Verdade LM (2018). Diversity and distribution patterns of medium to large mammals in a silvicultural landscape in south-eastern Brazil. iForest 11: 802-808. - doi: 10.3832/ifor2721-011 [online 2018-12-14]

Communicated by: Massimo Faccoli imposes the maintenance of legal conservation areas within silvicultural landscapes throughout south-eastern Brazil, which helps promote biodiversity through increased spatial heterogeneity (Fraterrigo et al. 2009).

Previous studies have shown that fauna diversity is relatively well represented within many agricultural and silvicultural landscapes dominated by Eucalyptus plantations in south-eastern Brazil, even when compared with areas of native vegetation (Dotta \& Verdade 2011, Verdade et al. 2014a, Timo et al. 2015). According to these studies, these areas are not only important corridors that facilitate movement between native habitats, but also provide opportunities for foraging and shelter for some species; therefore, having a potential conservation role.

The community structure of medium to large-sized mammals in human-modified landscapes may be a good indicator of ecosystem functionality, as these mammals may control prey/pest populations and facilitate the spread and germination of plant species (Noss et al. 1996, Jordano et al. 2006, Ripple \& Beschta 2006). Predator species can also play a role as a sentinel species, which are those animals that may be sensitive to ecosystem degradation. Thus, they are often the first species to disappear in disturbed or unhealthy habitats. In human-modified landscapes, mammalian carnivores are vulnerable to local extinction, as they require large home ranges and 
occur naturally in low densities (Noss et al. 1996). Further, coexistence between humans and large carnivores in agricultural areas is often complicated by the fact that these species are usually seen as a threat to humans or livestock and, therefore, face persecution (Marchini 2014). Consequently, monitoring medium to large-sized mammals in silvicultural systems is a crucial step for shaping environmental and public policies in multifunctional landscapes. The $12 \%$ of global land designated as protected areas (Joppa \& Pfaff 2010) is not sufficient for long-term conservation goals.

The objectives of this study were: (i) to assess species richness, number of families and number of trophic groups of medium to large mammals; (ii) to relate species richness, number of families and trophic groups within each habitat type that makes up this landscape (i.e., Eucalyptus plantations, native vegetation and abandoned pasture); (iii) to evaluate the spatial structure of medium to large mammals community in the silvicultural landscape during the second production cycle of this plantation situated in São Paulo, Brazil.

\section{Materials and methods}

\section{Study area}

This study was carried out at the farm Três Lagoas (3436 ha), which is part of the Programa de Pesquisa em Biodiversidade
(PPBio - Angatuba), Alto Paranapanema basin (23 $22^{\prime} 00^{\prime \prime}-23^{\circ} 20^{\prime} 41^{\prime \prime} \mathrm{S}$; $48^{\circ} 28^{\prime} 00^{\prime \prime}$ $\left.48^{\circ} 27^{\prime} 57^{\prime \prime} \mathrm{W}\right)$, São Paulo state, south-eastern Brazil (Fig. 1). The local climate is classified as subtropical (Cwa, according to the Köppen classification).

The landscape surrounding the Angatuba municipality was historically composed of coffee plantations, before being replaced by cotton plantations, and later, by citrus orchards and pastures (Martin et al. 2012, Lisboa 2014). From 1970, large areas of Eucalyptus and Pinus were established in the north of the municipality. Between 2006 and 2008, 2,220 ha of Eucalyptus were planted in Três Lagoas, with 880 ha allocated as Legal Reserve (LR) and 336 ha as Permanent Protection Areas (PPAs). This corresponds to $27.1 \%$ and $10.4 \%$ of the farm, respectively (Fig. 1), with the LR and PPAs predominantly located around riparian areas. PPAs and LRs are designated under the Brazilian Forest Code, which is a legal framework that regulates conservation and restoration of all natural vegetation in private land in Brazil. PPAs aim to protect water resources, soils and biodiversity, and are usually situated around waterways that must be covered by natural vegetation. LRs are portions of private land that aim to conserve biodiversity, where natural vegetation cannot be removed, although the location may be selected by the landowner.

Currently, Três Lagoas is made up of a
Fig. 1 - Study area. Location, habitat types and sampling units in Três Lagoas farm, PPBio - Angatuba, São Paulo state, southeast Brazil.

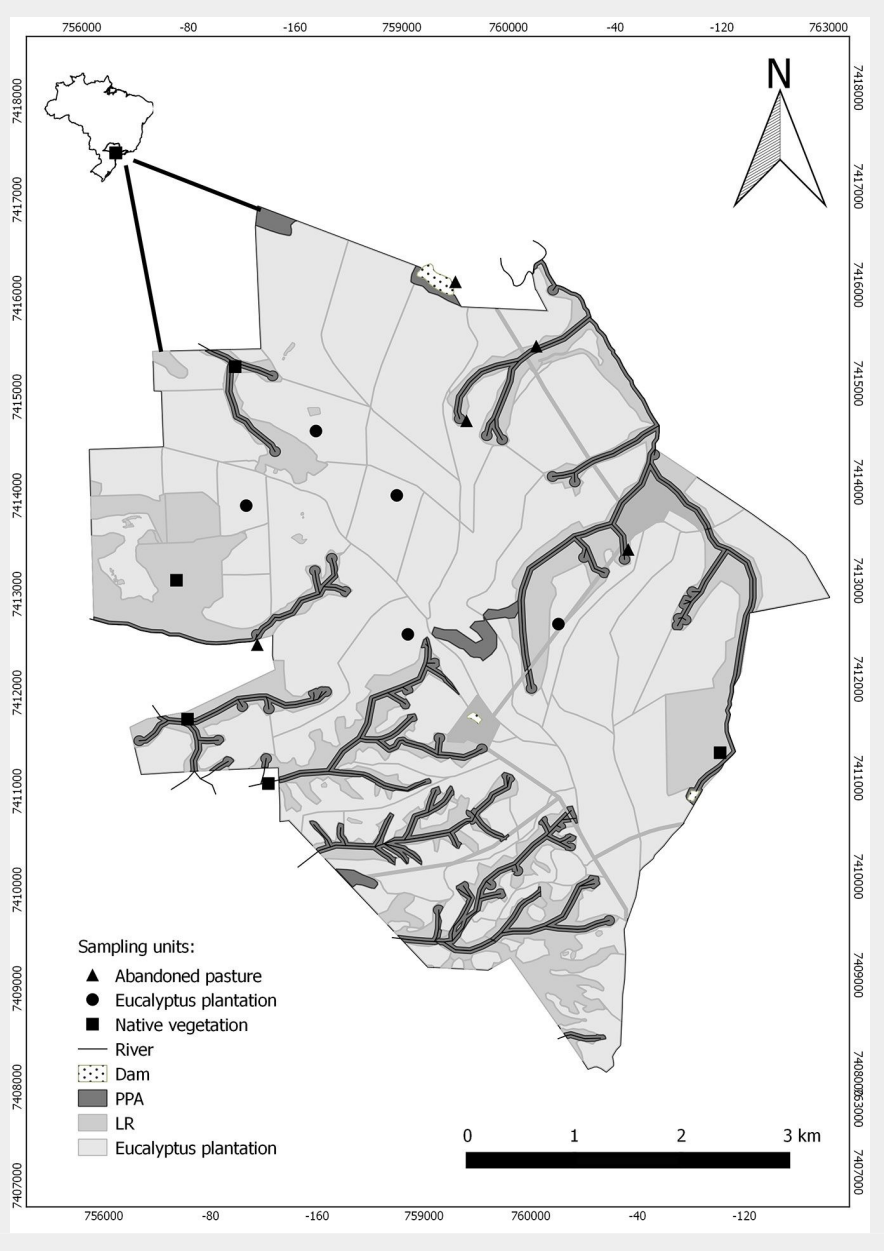

heterogenous landscape, with conservation areas and a Eucalyptus matrix (Athayde et al. 2016) on its second production cycle, where one production cycle last seven years. The native vegetation, such as cerrado sensu stricto, cerradão (forested savannah) and semi-decidual forest, makes up most of the PPAs, whereas abandoned pastures with native vegetation in various stages of regeneration mostly represents the LR within the farm (Athayde et al. 2016).

\section{Sampling methodology}

The present sampling methodology used a subsampling of a $1 \times 1 \mathrm{~km}$ regular spatial grid, which covered the study area, designed by PPBio of the Brazilian Ministry of Science and Technology (Magnusson et al. 2014). From this grid, five sampling units were selected from each habitat type (i.e., Eucalyptus plantations, native vegetation and abandoned pasture; $n=15$ - Fig. 1), where passive infrared camera trap stations (Bushnell Trophy Cam ${ }^{\circledast}$, Kansas City, MO, USA) were deployed approximately 40 centimetres above the ground, facing south.

The sampling period occurred from July 2015 to April 2016 and June to July 2016, in a total of twelve, one-week long, monthly field campaigns, totalling a sampling effort of 1260 trap-nights. No baits or lures were used, since these can attract or repel species differently and can bias the detection rates (Foster \& Harmsen 2012). Each camera trap was set to film for 15 seconds, to increase the chance of successful species identification, with a one-minute interval between videos. Consecutive records of the same species at the same site were deemed independent, when there was at least a one-hour interval between them (O'Brien et al. 2003). Where multiple individuals could be distinguished appearing simultaneously in the same video, each was counted as an individual record. The batteries were checked and replaced when necessary before each campaign.

Medium to large-sized mammals are classified as those species over one kilogram (Emmons \& Feer 1997). Those that were detected by the camera traps were documented at species level where possible. When identification to species level was not possible, the respective genus classification was used. Recorded species (or genus) were classified in trophic categories, adapted from Dotta \& Verdade (2007), as follows: carnivores, herbivores, omnivores, insectivores and frugivores. The number of individuals and the capture date and time of each video were also documented.

\section{Analytical methodology}

All medium to large-sized mammals were grouped in their orders, families and trophic groups. Sampling efficiency was assessed from the percentage of detected species related to the estimated number of species (i.e., Bootstrap asymptote), using 
Tab. 1 - Medium to large mammals detected, classified in their respective order, family and functional group, as well as the number of records of each species within each habitat type. (NV): Native vegetation; (AP): Abandoned pasture; (Eu): Eucalyptus plantations; (a): exotic invasive species.

\begin{tabular}{|c|c|c|c|c|c|c|c|}
\hline \multirow{2}{*}{ Order } & \multirow{2}{*}{ Family } & \multicolumn{2}{|l|}{ Species } & \multirow{2}{*}{$\begin{array}{l}\text { Functional } \\
\text { group }\end{array}$} & \multirow{2}{*}{ NV } & \multirow{2}{*}{ AP } & \multirow{2}{*}{ Eu } \\
\hline & & Scientific name & Common name & & & & \\
\hline \multirow[t]{4}{*}{ Artiodactyla } & Cervidae & Mazama americana cf. & Red Brocket & Herbivore & 2 & 1 & 4 \\
\hline & & Mazama gouazoubira & Gray Brocket & Herbivore & 2 & 0 & 1 \\
\hline & Suidae & Sus scrofa ${ }^{\text {a }}$ & Wild Boar & Omnivore & 1 & 1 & 1 \\
\hline & Tayassuidae & Pecari tajacu & Collared Peccary & Omnivore & 12 & 3 & 5 \\
\hline \multirow[t]{7}{*}{ Carnivora } & Canidae & Cerdocyon thous & Crab-eating Fox & Omnivore & 2 & 1 & 0 \\
\hline & & Chrysocyon brachyurus & Maned Wolf & Omnivore & 0 & 1 & 5 \\
\hline & Felidae & Leopardus guttulus & Oncilla & Carnivore & 1 & 2 & 0 \\
\hline & & Leopardus sp. & Small cat & Carnivore & 0 & 0 & 1 \\
\hline & & Puma concolor & Puma & Carnivore & 3 & 1 & 2 \\
\hline & Mustelidae & Eira barbara & Tayra & Omnivore & 3 & 0 & 0 \\
\hline & Procyonidae & Nasua nasua & South American Coati & Omnivore & 4 & 0 & 3 \\
\hline \multirow[t]{2}{*}{ Cingulata } & Dasypodidae & Cabassous unicinctus & Southern Naked-Tailed Armadillo & Insectivore & 1 & 3 & 1 \\
\hline & & Dasypus novemcinctus & Nine-banded Armadillo & Insectivore & 0 & 12 & 3 \\
\hline \multirow[t]{2}{*}{ Lagomorpha } & Leporidae & Lepus europaeus $^{\text {a }}$ & European Hare & Herbivore & 0 & 4 & 1 \\
\hline & & Sylvilagus brasiliensis & Tapeti & Herbivore & 0 & 3 & 0 \\
\hline \multirow[t]{2}{*}{ Pilosa } & Myrmecophagidae & Myrmecophaga tridactyla & Giant Anteater & Insectivore & 4 & 2 & 6 \\
\hline & & Tamandua tetradactyla & Southern Tamandua & Insectivore & 1 & 2 & 0 \\
\hline \multirow[t]{2}{*}{ Rodentia } & Cuniculidae & Cuniculus paca & Spotted Paca & Frugivore & 2 & 0 & 0 \\
\hline & Erethizontidae & Coendou sp. & Brazilian Porcupine & Herbivore & 0 & 0 & 1 \\
\hline
\end{tabular}

the software package Estimates Win 7 2010). Because heterogeneous landscapes

(Colwell et al. 2004). We ran the paired t- contain multiple habitat types that can test to assess interannual variability in the number of species detected in the campaigns carried out in July 2015 and 2016.

A histogram of the species was generated to evaluate the frequency of detection for each species within the study area and within each habitat type (i.e., native vegetation, abandoned pasture and Eucalyptus plantations). Differences between habitats in terms of species richness, number of families, number of trophic groups and frequency of occurrence were assessed by one-way ANOVA (Hector et al. vary in community structure, a Venn diagram was used to show assemblage distribution and identify possible overlaps among species in terms of habitat use (Moktefi \& Shin 2012).

\section{Results}

We detected seventeen native and two exotic invasive medium-to-large mammal species. Among these, the maned wolf (Chrysocyon brachyurus), oncilla (Leopardus guttulus), giant anteater (Myrmecophaga tridactyla) and puma (Puma conco- lor) are listed as threatened at some level in São Paulo state, as well as in the Brazilian national list (Percequillo \& Kierulff 2009). Globally, L. guttulus and M. tridactyla are both listed as vulnerable (IUCN 2015). The European hare (Lepus europaeus) and wild boar (Sus scrofa) are considered exotic and invasive species in Brazil. The following trophic categories were detected: herbivores, carnivores, omnivores, frugivores and insectivores (Tab. 1). Bootstrap analyses suggest that $91.1 \%$ of the local species were detected within this silvicultural landscape, whilst $83.2 \%$ were detected in each habitat type (Fig. 2). The
Fig. 2 - Species incidence curve. (a) Study area; (b), (c) and (d) Habitat types.

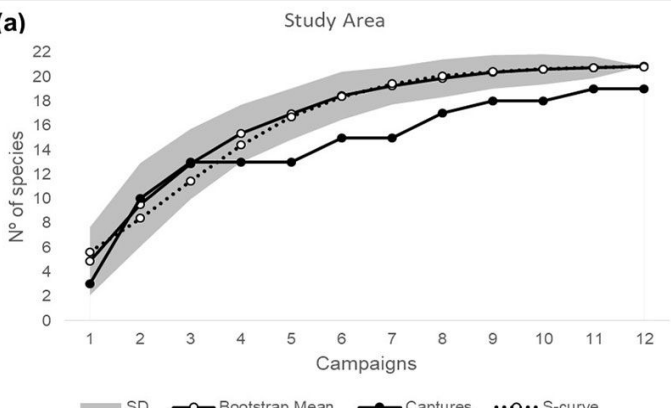

(c)

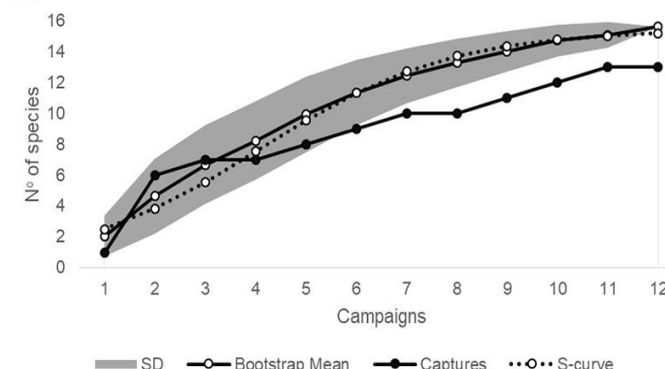

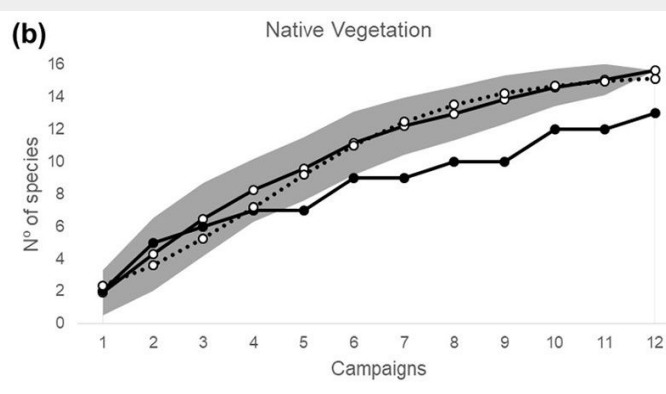

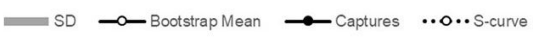

(d)

Eucalyptus

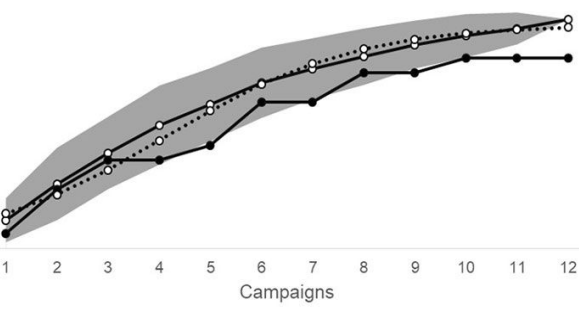

$=$ SD $\rightarrow$ Bootstrap Mean $\rightarrow$ Captures $\quad$..o.. S-curve 


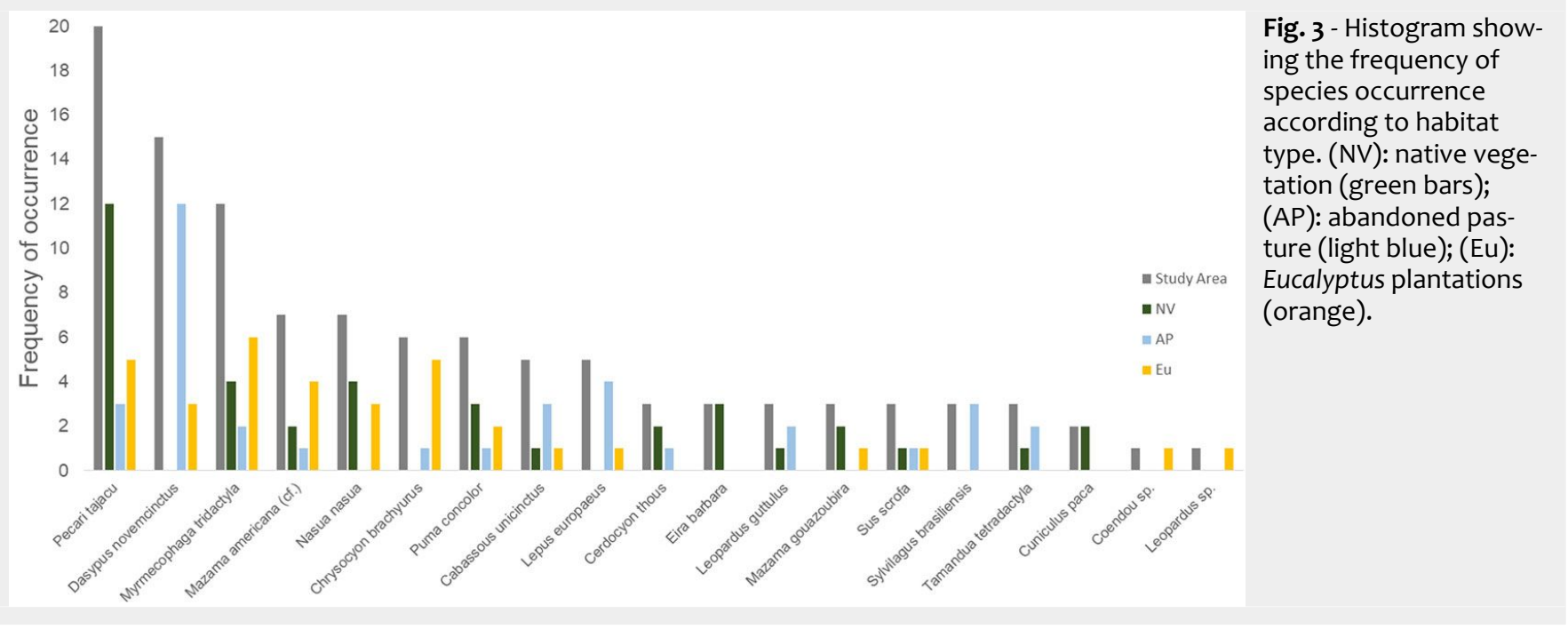

campaigns carried out in July 2015 and 2016 showed a significant difference in the number of species detected $(\mathrm{df}=10, t=3.13, \mathrm{p}=$ 0.011).

The histogram shows the frequency of occurrence of the species within each habitat type. The collared peccary (Pecari tajacu) was the species most frequently detected within the study area $\left(n_{\mathrm{sa}}=20\right)$ and in native vegetation fragments $\left(n_{n v}=12\right)$. The nine-banded armadillo (Dasypus novemcinctus) and $M$. tridactyla were the species most commonly detected within abandoned pasture $\left(n_{a p}=12\right)$ and in Eucalyptus plantations ( $\mathrm{n}_{\mathrm{eu}}=6$ ), respectively (Fig. 3). Species richness $(\mathrm{df}=14, \mathrm{~F}=0.50, \mathrm{p}=$ 0.617 ), number of phylogenetic families ( $\mathrm{df}$ $=14, F=0.75, p=0.494)$, number of trophic groups $(d f=14, F=0.34, p=0.717)$ and frequency of occurrence (df $=14, F=0.04, p=$ $0.965)$ showed no significant differences among habitat types.

The Venn diagram shows that most medium to large-sized mammals were found in all three, or at least two, habitat types that made up the study area, and 13 species were found in each habitat type. Five species (i.e., paca - Cuniculus paca, Brazil-

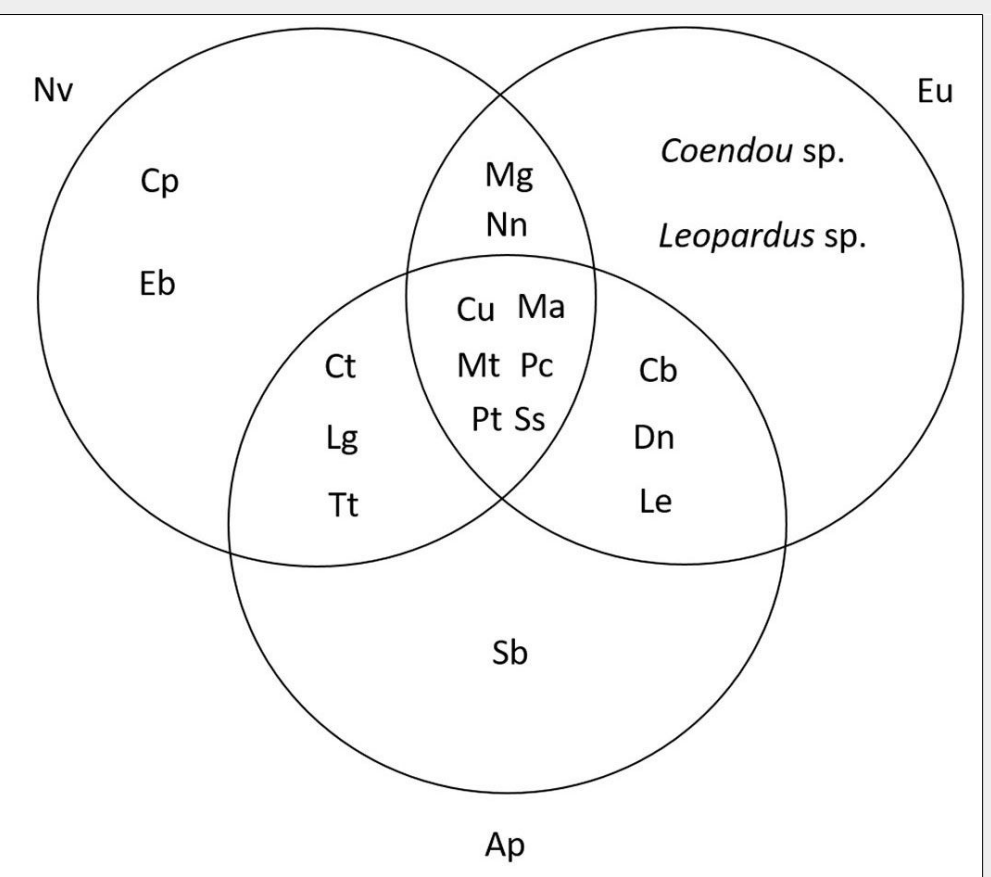

Fig. 4 - Venn diagram: relationship between medium to large mammals and the environments of a landscape dominated by Eucalyptus plantations. Species abbreviations: (Cb): Chrysocyon brachyurus; (Cp): Cuniculus paca; (Ct): Cerdocyon thous; (Cu): Cabassous unicinctus; (Dn): Dasypus novemcinctus; (Eb): Eira barbara, (Le): Lepus europaeus; (Lg): Leopardus guttulus; (Ma): Mazama americana (cf.); (Mg): Mazama gouazoubira; (Mt): Myrmecophaga tridactyla; (Nn): Nasua nasua; (Pc): Puma concolor; (Pt): Pecari tajacu; (Sb): Sylvilagus brasiliensis; (Ss): Sus scrofa; (Tt): Tamandua tetradactyla; (Eu): Eucalyptus plantations; (AP): abandoned pasture; (NV): native vegetation. ian porcupine - Coendou sp., small cat Leopardus sp., L. guttulus and tapeti - Sylvilagus brasiliensis) were present in only one habitat (Fig. 4).

\section{Discussion}

All species detected were expected to occur in the area, according to previous studies carried out in similar landscapes (Dotta \& Verdade 2011, Timo et al. 2015), and most are considered generalists in terms of habitat and resource use. We did not detect the presence of some forest specialist species (e.g., Agouti sp.) and species related to water habitats (e.g., capybaras - Hydrochoerus hydrochaeris), which may be due to methodological constraints (i.e., cameras placed away from water sources). Also, large seed dispersers (e.g., tapir - Tapirus terrestris and white-lipped peccary - Tayassu pecari) and species detected during a simultaneous sign-survey that was conducted in the area (i.e., racoon - Procyon lotor, hoary fox - Lycalopex vetulus and hog-nosed skunk - Conepatus spp.) were not captured by camera traps. Although these species are likely to have small population densities, their non-detection may also be due to methodological constraints (Dotta \& Verdade 2011). Rare species are likely to need a larger sampling effort to be detected (Mackenzie et al. 2005).

Nonetheless, the present data shows that the study area is inhabited by threatened species, such as C. brachyurus, L. guttulus, $M$. tridactyla and $P$. concolor, which adds conservation value to silvicultural landscapes. Wild boar (Sus scrofa) and European hare (Lepus europaeus), whilst having the potential to act as seed dispersers and thus taking over the ecological role of native animals (Donatti et al. 2007), are generally considered to have negative impacts on ecosystems by introducing diseases, damaging crops and forest patches, and competing with native species (Pedrosa et al. 2015). Given the amount of area that these landscapes cover, and their potential to support populations of a relatively diverse range of wildlife, medium to large 
mammals inhabiting this landscape are worthy of being monitored to take effective management actions (i.e., conservation, control or sustainable use of species) to improve local biodiversity and biocomplexity, as suggested by Verdade et al. (2014b).

Species richness within the study site was similar to other studies carried out in areas of Atlantic forest, semi-deciduous forest and Cerrado in São Paulo state, where 15 to 27 medium to large mammals were detected (Dotta \& Verdade 2011, Timo et al. 2015). Bootstrap analysis suggests that our sampling effort was sufficient to detect most of the species present in the area, in comparison with similar studies (Dotta 2005, Timo et al. 2015) and that sampling periods of at least one year should be used in future studies in similar habitats.

The species histogram of the study area shows a common pattern in ecology; most species found are rare and few species are abundant (May et al. 2007). P. tajacu can live in large groups from two to 50 individuals (Sowls 1984) and was detected in groups of up to six individuals during this survey and was the most abundant species. D. novemcinctus and $M$. tridactyla have an insect-based diet, ants and termites in particular, which are commonly found in high densities in Eucalyptus plantations (Medri et al. 2003).

The difference between the number of species detected in 2015 and 2016 may be due to environmental factors, such as rain frequency. São Paulo state had unusual rain in June 2016 (Clima Tempo 2016), which may have contributed to higher vegetation growth and food availability.

In this study, species richness shows high variability among sampling units within all habitat types, leading to non-significant differences among habitat types. This may be explained by the fact that, in this study area, native vegetation and pasture vary greatly in vegetation structure, and patches of native vegetation (PPAs and LRs) are unevenly distributed across the landscape (Athayde et al. 2016). However, Dotta \& Verdade (2011) found variation in species richness between habitat types, i.e., Eucalyptus plantations, sugarcane, native fragments and pasture.

Twelve families were detected within the study area, which is consistent with other studies carried out in similar landscapes, where the number of families varied from 12 to 14 (Dotta \& Verdade 2011, Alves et al. 2012). The present results suggest that this landscape maintains a similar number of phylogenetic families in each habitat.

Habitat modification caused by humans may alter the relationship between species. One possible way to protect species interaction is by maintaining diversity of functional groups, as functional diversity measures the variation of characteristics in the community (Flynn et al. 2009). All habitats presented high variation in terms of functional groups across the sampling units. This may be because abandoned pasture and native vegetation have different levels of regenerated vegetation, and the Eucalyptus biomass varies along the productive cycle (Stape et al. 2004), creating a relatively high degree of spatial and temporal heterogeneity across the landscape, promoting rich biodiversity (Martin et al. 2012, Timo et al. 2015). The number of functional groups was consistent with studies carried out in similar landscapes (Dotta \& Verdade 2011, Alves et al. 2012).

In the present study, no difference was detected in the frequency of occurrence among habitat types, suggesting that the detectability of those species was similar across the different habitats. However, Dotta \& Verdade $(2007,2011)$ found a consistent difference in relative abundance of medium to large-sized mammals in an agricultural landscape with distinct matrices, with sugarcane plantations showing the highest frequency of occurrence. This difference may be due to the fact that the current study consisted solely of Eucalyptus plantations as the matrix.

The Venn diagram suggests that most medium to large-sized mammal species found in the study area are generalists, and use the area as a whole, being able to cross the mosaic of habitats. This may be related to some degree of plasticity in the modified habitat, and variable habitat or food requirements (Verdade 1996, Dotta \& Verdade 2011, Verdade et al. 2011). According to Dotta \& Verdade (2007), a similarity concerning the number of species between habitats, with few species occurring in just one or two habitat types, indicates a relatively uniform trophic structure in mammal assemblages among environments in silvicultural landscapes. However, the only frugivorous species found was the paca (C. paca), with a single record within the native vegetation. This suggests that $C$. paca may be sensitive to habitat modification, given the low population density in the study area.

Conservation management aims to conserve wildlife, as well as ecosystem functionality and complexity; hence, the ecological complexity of native vegetation patches within the silvicultural landscape should be improved to help the recovery of frugivorous species. Mesopredator species, such as L. gutullus and E. barbara, with their ability to exploit a range of food resources from different habitats, may benefit from agricultural landscapes (Crooks 2002).

Most silvicultural landscapes with a Eucalyptus matrix in south-east Brazil follow the land-sharing approach, with larger areas designated for production and smaller areas designated for permanent protection (Green et al. 2005). Green et al. (2005) have shown that there can be more biodiversity in such landscapes when they are not solely managed for production. Our results stress the role of multifunctional landscapes in promoting wildlife conservation
(Verdade et al. 2014a, 2016), due to the fact that the current protected area network is insufficient to maintain biodiversity (Ekroos et al. 2016).

\section{Final considerations}

Although many species of medium to large mammals were shown to inhabit areas within the silviculture matrix, PPAs and LR are fundamental to the maintenance of functional diversity, especially for forest specialist and frugivorous species. This study shows that silvicultural landscapes demand wildlife management efforts (i.e., biodiversity conservation, control, sustainable use and monitoring) and stresses the conservation role of multifunctional landscapes (Verdade et al. 2016). The relatively high diversity of predators suggests the possible use of trophic approaches in future monitoring programs of biodiversity and biocomplexity in silvicultural landscapes (Verdade et al. 2014a). Consequently, future studies should prioritise the use of wildlife-friendly agricultural management techniques, as well as the reintroduction of locally extinct species of large mammals, like the tapir, to recover the complexity level of ecological and evolutionary processes and the consequent patterns of biological diversity. However, this can be done only after the causes that induced the extinction of these species are identified and mitigated. Further, similar studies should be conducted in different landscapes, to evaluate the true contribution of the spatial arrangement of conservation areas to the survivorship of medium to large-sized mammals. Last, but not least, long-term cross-scale monitoring programs should be established in agricultural landscapes to improve the decision-making process concerning wildlife management.

\section{Acknowledgements}

$B M C$ and JDC carried out the field surveys, performed the statistical analysis and drafted the manuscript. LMV conceived the study, helped establish the field surveys and perform statistical analyses, and assisted with writing the manuscript. This work was financially supported by the Agência Nacional de Energia Elétrica, Brazil (ANELL; Proc. no. 0064-1036/2014). LMV holds a productive fellowship from Conselho Nacional de Desenvolvimento Científico e Tecnológico, Brazil (CNPq; Proc. no. 309468/2011-6). We would like to thank Biota Program Fapesp, PPBio/MCT and Duratex S.A.

\section{Conflicts of interest}

The authors declare that they have no conflict of interest.

\section{References}

Alves TRU, Fonseca RCB, Engel VL (2012). Mamíferos de médio e grande porte e sua relação com o mosaico de habitats na cuesta de Botucatu, Estado de São Paulo, Brasil [Medium and large sized mammalians and their relation to 
habitat patches at the Botucatu cuesta, state of São Paulo, Brazil]. Iheringia: Série Zoologia 102: 150-158. [in Portuguese] - doi: 10.1590/So07 3-47212012000200006

Athayde EA, Cancian LF, Morellato LPC (2016). The value of agricultural landscape for tropical trees. In: "Biodiversity in Agricultural Landscapes of Southeastern Brazil" (Gheler-Costa C, Lyra-Jorge MC, Verdade LM eds). De Gruyter Open, Berlin, pp. 87-103. [online] URL: http:// www.degruyter.com/downloadpdf/books/9783 110480849/

Cianciulli PL (1954). Introdução de essências florestais [Introduction to forestry bases]. Secretaria da Agricultura, Serviço Florestal, São Paulo, Brazil, pp. 30. [in Portuguese]

Clima Tempo (2016). São Paulo tem terceiro junho mais chuvoso em 73 anos [São Paulo has the rainiest June in 73 years]. Web site. [online] URL: http://www.climatempo.com.br/noticia/2 016/06/07/sao-paulo-tem-terceiro-junho-maischuvoso-em-73-anos-3901

Colwell RK, Mao CX, Chang J (2004). Interpolating, extrapolating, and comparing incidencebased species accumulation curves. Ecology 85 (10): 2717-2727. - doi: 10.1890/03-0557

Crooks KR (2002). Relative sensitivities of mammalian carnivores to habitat fragmentation. Conservation Biology 16 (2): 488-502. - doi: 10.1046/j.1523-1739.2002.00386.x

Donatti $\mathrm{Cl}$, Galetti M, Pizo MA, Guimaraes PR, Jordano P (2007). Living in the land of ghosts: fruit traits and the importance of large mammals as seed dispersers in the Pantanal, Brazil. In: "Seed Dispersal: Theory and its Application in a Changing World" (Dennis AJ, Schupp EW, Green RJ, Westcott DA eds). CSIRO Sustainable Ecosystems and the Rainforest CRC, Australia, pp. 104-121. - doi: 10.1079/9781845931650.0104 Dotta G (2005). Diversidade de mamíferos de médio e grande porte em relação à paisagem da Bacia do Rio Passa-Cinco, São Paulo [Diversity of medium and large-sized mammals in relation to the landscape atributes in the PassaCinco river basin, São Paulo]. Master's thesis, Universidade de São Paulo, Piracicaba, SP, Brazil, pp. 116. - doi: 10.11606/D.91.2005.tde-070 72005-150411

Dotta G, Verdade LM (2007). Trophic categories in a mammal assemblage: diversity in an agricultural landscape. Biota Neotropica 7 (2): 287292. - doi: 10.1590/S1676-06032007000200031

Dotta G, Verdade LM (2011). Medium to largesized mammals in agricultural landscapes of south-eastern Brazil. Mammalia 75 (4): 345-352. - doi: 10.1515/MAMM.2011.049

Ekroos J, Odman AM, Andersson GK, Birkhofer K, Herbertsson L, Klatt BK, Olsson O, Olsson PA, Persson AS, Prentice HC, Rundlöf M, Smith HG (2016). Sparing land for biodiversity at multiple spatial scales. Frontiers in Ecology and Evolution 3: 145. - doi: 10.3389/fevo.2015.00145 Emmons L, Feer F (1997). Neotropical rainforest mammals: a field guide ( $2^{\text {nd }}$ edn). University of Chicago Press, Chicago, USA, pp. 396.

Flynn DFB, Gogol-Prokurat M, Nogeire T, Molinari N, Richers BT, Lin BB, Simpson N, Mayfield $M M$, Declerck F (2009). Loss of functional diversity under land use intensification across multiple taxa. Ecology Letters 12 (1): 22-33. - doi: 10.1111/j.1461-0248.2008.01255.x
Foley JA, DeFries R, Asner GP, Barford C, Bonan G, Carpenter SR, Chapin FS, Coe MT, Daily GC, Gibbs HK, Helkowski JH, Holloway T, Howard EA, Kucharik CJ, Monfreda C, Patz JA, Prentice IC, Ramankutty N, Snyder PK (2005). Global consequences of land use. Science 309: 570-74. doi: 10.1126/science.1111772

Foster RJ, Harmsen BJ (2012). A critique of density estimation from camera-trap data. Journal of Wildlife Management 76 (2): 224-236. - doi: 10.1002/jwmg.275

Fraterrigo JM, Pearson SM, Turner MG (2009). Joint effects of habitat configuration and temporal stochasticity on population dynamics. Landscape Ecology 24: 863-877. - doi: 10.1007/ s10980-009-9364-6

Green RE, Cornell SJ, Scharlemann JPW, Balmford A (2005). Farming and the fate of wild nature. Science 307: 550-555. - doi: 10.1126/scien ce.1106049

Hector A, Von Felten S, Schmid B (2010). Analysis of variance with unbalanced data: an update for ecology and evolution. Journal of Animal Ecology 79 (2): 308-316. - doi: 10.1111/j.1365-265 6.2009.01634.x

IBGE (2015). Produção da extração vegetal e da silvicultura - PEVS [Production of the vegetable extraction and silviculture]. Web site. [online] URL: http://www.sidra.ibge.gov.br/bda/pesqui sas/pevs/default.asp

IUCN (2015). The IUCN red list of threatened species. Version 2015-4. Web site. [online] URL: http://www.iucnredlist.org

Joppa LN, Pfaff A (2010). Global protected area impacts. Proceedings of the Royal Society B: Biological Sciences 278 (1712): 1633-1638. - doi: 10.1098/rspb.2010.1713

Jordano P, Galetti M, Pizo MA, Silva WR (2006). Ligando frugivoria e dispersão de sementes à biologia da conservação [Linking frugivory and seed dispersal to biological conservation]. In: "Biologia da Conservação: Essências" (Duarte CF, Bergallo HG, Dos Santos MA, Va AE eds). Editorial Rima, São Paulo, Brazil, pp. 411-436. [in Portuguese]

Lisboa MAM (2014). A política dos coronéis e a difusão do ensino primário em Angatuba/SP (1870-1930) [The politics of the crows and the diffusion of the elementary school in Angatuba/SP (1870-1930)]. PhD Thesis, Universidade de Campinas, São Paulo, Brazil, pp. 204. [in Portuguese]

Mackenzie DI, Nichols J, Sutton N, Kawanishi K, Bailey LL (2005). Improving inferences in population studies of rare species that are detected imperfectly. Ecology 86 (5): 1101-1113. - doi: 10.1890/04-1060

Magnusson WE, Lawson B, Baccaro F, Castilho CV, Castley JG, Costa F, Drucker DP, Franklin E, Lima AP, Luizão R, Mendonça F, Pezzini F, Schietii J, Toledo JJ, Tourinho A, Verdade LM, Hero $J$ (2014). Multi-taxa surveys: integrating ecosystem processes and user demands. In: "Applied Ecology and Human Dimensions in Biological Conservation" (Verdade LM, Lyra-Jorge MC, Piña $\mathrm{Cl}$ eds). Springer, Berlin, Heidelberg, Germany, pp. 177-187. - doi: 10.1007/978-3-642-5475 15_12

Marchini S (2014). Who's in conflict with whom? Human dimensions of the conflicts involving wildlife. In: "Applied Ecology and Human Di- mensions in Biological Conservation" (Verdade LM, Lyra-Jorge MC, Piña Cl eds). Springer, Berlin, Heidelberg, pp. 189-209. - doi: 10.1007/9783-642-54751-5_13

Martin PS, Gheler-Costa C, Lopes PC, Rosalino LM, Verdade LM (2012). Terrestrial non-volant small mammals in agro-silvicultural landscapes of south-eastern Brazil. Forest Ecology and Management 282: 185-195. - doi: 10.1016/j.for eco.2012.07.002

Maxwell S, Fuller RA, Brooks TM, Watson JEM (2016). The ravages of guns, nets and bulldozers. Nature 536 (7615): 143-145. - doi: 10.1038/5 $36143 a$

May RM, Crawley MJ, Sugihara G (2007). Communities: patterns. In: "Theoretical Ecology: Principle and Applications" (May RM, McLean AR eds). Oxford University Press, Oxford, UK, pp. 111-131. [online] URL: http://books.google. com/books?id=BpESDAAAQBAJ

Medri IM, Mourão GM, Harada AY (2003). Dieta de tamanduá-bandeira (Myrmecophaga tridactyla) no Pantanal da Nhecolndia, Brasil [Diet of giant-anteater (Myrmecophaga tridactyla) at Nhecolndia Pantanal, Brazil]. Edentata 5: 29-34. [in Portuguese with English abstract] [online] URL: http://www.asasg.org/resources/bibliogra phy/70Edentata

Moktefi A, Shin SJ (2012). A history of logic diagrams. In: "Handbook of the History of Logic" (Gabbay DM, Pelletier FJ, Woods J eds). NorthHolland, Elsevier, pp. 611-682. - doi: 10.1016/B9 78-0-444-52937-4.50011-3

Noss RF, Quigley HB, Hornocker MG, Merrill T, Paquet PC (1996). Conservation biology and carnivore conservation in the Rocky Mountains. Conservation Biology 10: 949-963. - doi: 10.1046/j.1523-1739.1996.10040949.x

O'Brien TG, Kinnaird MF, Wibisono HT (2003). Crouching tigers, hidden prey: Sumatran tiger and prey populations in a tropical forest landscape. Animal Conservation 6: 131-139. - doi: 10.1017/S1367943003003172

Pedrosa F, Salerno R, Padilha FVB, Galetti M (2015). Current distribution of invasive feral pigs in Brazil: economic impacts and ecological uncertainty. Natureza and Conservação 13: 8487. - doi: 10.1016/j.ncon.2015.04.005

Percequillo AR, Kierulff C (2009). Mamíferos [Mammals]. In: "Fauna Ameaçada de Extinção do Estado de São Paulo: Vertebrados” (Breassan PM, Kierulff MCM, Sugieda AM eds). Fundação Parque Zoológico de São Paulo, Secretaria do Meio Ambiente, São Paulo, Brazil, pp. 31-41. [in Portuguese]

Ripple WJ, Beschta RL (2006). Linking a cougar decline, trophic cascade, and catastrophic regime shift in Zion National Park. Biological Conservation 133: 397-408. - doi: 10.1016/j.biocon.20 06.07 .002

Sowls LK (1984). The peccaries. University of Arizona Press, Tucson, AZ, USA, pp. 240.

Sparovek G, Berndes G, Klug IL, Barretto AGDOP (2010). Brazilian agriculture and environmental legislation: status and future challenges. Environmental Science and Technology 44 (16): 6046-6053. - doi: 10.1021/es1007824

Stape JL, Binkley D, Ryan MG (2004). Eucalyptus production and the supply, use and efficiency of use of water, light and nitrogen across a geographic gradient in Brazil. Forest Ecology and 
Management 193 (1-2): 17-31. - doi: 10.1016/j.for ec0.2004.01.020

Timo TPC, Lyra-Jorge MC, Gheler-Costa C, Verdade LM (2015). Effect of the plantation age on the use of Eucalyptus stands by medium to large-sized wild mammals in south-eastern Brazil. iForest 8: 108-113. - doi: 10.3832/ifor1237-008 Verdade LM (1996). The influence of hunting pressure on the social behavior of vertebrates. Revista Brasileira de Biologia 56 (1): 1-13. [online] URL: http://www.esalq.usp.br/docentes/ lea/Artigos_pdf/Verdade1996.PDF

Verdade LM, Gheler-Costa C, Lyra-Jorge MC (2016). The multiple facets of agricultural landscapes. In: "Biodiversity in Agricultural Landscapes of Southeastern Brazil" (Gheler-Costa C,
Lyra-Jorge MC, Verdade LM eds). De Gruyter, Berlin, Germany, pp. 2-13. - doi: 10.1515/9783110 480849-003

Verdade LM, Lyra-Jorge MC, Piña Cl (2014a). Redirections in conservation biology. In: "Applied Ecology and Human Dimensions in Biological Conservation" (Verdade LM, Lyra-Jorge $\mathrm{MC}$, Piña Cl eds). Springer-Verlag, Heidelberg, Germany, pp. 3-17. - doi: 10.1007/978-3-642-54 751

Verdade LM, Penteado M, Gheler-Costa C, Dotta G, Rosalino LM, Pivello VR, Piña Cl, Lyra-Jorge MC (2014b). The conservation value of agricultural landscapes. In: "Applied Ecology and Human Dimensions in Biological Conservation" (Verdade LM, Lyra-Jorge MC, Piña $\mathrm{Cl}$ eds).
Springer-Verlag, Berlin, Heidelberg, Germany, pp. 91-102. - doi: 10.1007/978-3-642-54751-5_6 Verdade LM, Rosalino LM, Gheler-Costa C, Pedroso NM, Lyra-Jorge MC (2011). Adaptation of mesocarnivores (Mammalia: Carnivora) to agricultural landscapes in Mediterranean Europe and south-eastern Brazil: a trophic perspective. In: "Middle-Sized Carnivores in Agricultural Landscapes" (Rosalino LM, Gheler-Costa C eds). Nova Science Publishers, Inc., New York, USA, pp. 1-38. [online] URL: http://www.re searchgate.net/publication/232417256

World Bank (2018). Agricultural land (\% of land area). Web site. [online] URL: http://data.world bank.org/indicator/AG.LND.AGRI.ZS?end $=2015 \&$ start $=1961 \&$ view $=$ chart 